\title{
Post-Traumatic Stress Disorder among the Adolescents Reside in Padang's Prone Earthquake Area in West Sumatera, Indonesia
}

\author{
Firdawati, Rosnah Sutan \\ Department of Community Health, Universiti Kebangsaan Malaysia, Kuala Lumpur, Malaysia \\ Email:rosnah_sutan@yahoo.com
}

How to cite this paper: Firdawati and Sutan, R. (2017) Post-Traumatic Stress Disorder among the Adolescentsreside in Padang's Prone Earthquake Area in West Sumatera, Indonesia. Health, 9, 1301-1312. https://doi.org/10.4236/health.2017.99094

Received: July 13, 2017

Accepted: September 4, 2017

Published: September 7, 2017

Copyright $\odot 2017$ by authors and Scientific Research Publishing Inc. This work is licensed under the Creative Commons Attribution International License (CC BY 4.0).

http://creativecommons.org/licenses/by/4.0/

\begin{abstract}
The prevalence of post-traumatic stress disorder (PTSD) among the adolescents after earthquakes is not commonly reported in Indonesia. However, symptoms of PTSD such as loss of concentration, re-experiencing, avoidance and numbing commonly presented to the medical staffs even two years after $30^{\text {th }}$ September of 2009 which was the worst earthquakes in Indonesia. The present study aimed to assess the relationship between individual characteristics, family status and cognitive factors (coping strategies and self-efficacy) with PTSD among adolescents in earthquake prone areas. Padang, West Sumatera was chosen after the occurrence of the earthquake on $30^{\text {th }}$ September 2009. A cross sectional study was conducted on randomly selected 600 adolescents using revised University of California, Los Angeles Reaction Index (UCLA-RI) questionnaire to measure PTSD, levels of trauma and coping strategies. The result showed that the prevalence of PTSD among adolescents aged 12 - 18-year-old at 32 months after the earthquake was $36 \%$. The adolescents' age $(p<0.01)$, gender $(p<0.01)$, coping strategies $(p=0.04)$ and self-efficacy $(p=0.02)$ were significantly associated with the PTSD. Parental status, family income and parents' education status were found not related to PTSD. Parents and school teachers must be alerted on the important of adolescents' physical and mental health screening post traumatic disaster such as earthquake even though adolescents are well known of fit and healthy group. Good coping strategies and having strong self-efficacy were found useful tool to buffer and reduce the occurrence of PTSD.
\end{abstract}

\section{Keywords}

Earthquake, PTSD, Adolescents, Coping Strategies and Self-Efficacy 


\section{Introduction}

Padang is the capital of Indonesia's West Sumatra province and lies on Sumatra's west coast with a width of $694.96 \mathrm{~km}$. Padang city consists of 11 districts and 104 villages [1]. The population of the community in Padang is 856,815 people who consist of 423,039 men and 433,776 women and the human growth index is $2.31 \%$ per year. The biggest age group is 15 - 64 years old with a proportion of $68 \%$. The level of education above high elementary school (SMU) was only 2847 people [1].

Earthquakes were higher than 6 on the Richter scale happened many times in West Sumatera in a period of time from January 2009 to August 2011 [2]. The highest magnitude of earthquakes that occurred in Padang and West Sumatera on Wednesday, $30^{\text {th }}$ September 2009 at 5:16 pm at local time which had a magnitude of 7.9 on the Richter scale. The epicenter was 45 kilometers (28 miles) in the west-northwest of Padang, Sumatera [2]. The impact of the earthquake was felt not only by adults but also by children and adolescents who had worries, anxiety, fears and even depression or stress [2]. One form of psychological effects often encountered in the adolescent disaster victims after the earthquake was Post Traumatic Stress Disorder (PTSD). The government of Indonesia reported that 1195 people were killed, 1214 were seriously injured and 1688 suffered minor injuries. Most of the deaths occurred in the Padang Pariaman area (675 people), Padang (313 people), Agam (80 people) and the city of Pariaman (37 people). In addition, around 135,000 houses were severely damaged, 65,000 houses were damaged and 79,000 houses were partially damaged. An estimated 250,000 families (1,250,000 people) have been affected by the earthquake [2].

PTSD is a disorder that is caused by traumatic events that threaten the safety of someone or make someone powerless [3]. National Institute of Mental Health (NIMH) defines PTSD as a type of anxiety disorder that occurs after trauma or traumatic events [4]. High magnitude of earthquake can cause secondary stressors (psychosocial loss, decrease in academic performance, media terror, etc.).

Not all earthquake survivors suffered PTSD. It depends on the factors that influence them. One of these factors is the cognitive factor that consists of coping strategies and self-efficacy. Self-efficacy means how one's perception has the potency and ability to influence their own behavior, motivations, thoughts and emotions during stressful situations [5]. Self-efficacy was believed to aid the person during a period of stress. With confidence, adolescents will be able to face their future life. Any obstacles and challenges they faced and all of the issues that matter will be able to be overcome by them. Having good self-efficacy, especially for the adolescents can help them in becoming optimistic and courageous in life.

Coping ability is the attempt by the individual to manage external and internal demands that were caused by sources of stress [6]. Coping abilities are special efforts, both behavioral and psychological, which are used by the individual to master, tolerate, reduce or minimize the impact of stressful events. Good coping abilities are required for adolescents to allow them to solve their problems cor- 
rectly [7]. The present study aimed to determine the prevalence of PTSD and its association with coping strategies and self-efficacy among adolescents living in the earthquake prone area of Padang, West Sumatera Province, Indonesia. According to the World Health Organization (WHO), adolescents include those who are of 10 - 19 years of age [8]. The law of Indonesian Republic No. 23/2002 stated that the age of adolescents defined as 10 - 18 years old [9].

\section{Methodology}

\subsection{Study Design and Sample Population}

A population-based cross-sectional study was conducted in Padang Sumatera Indonesia; 32 months post highest magnitude of earthquake day in Indonesia which was the $30^{\text {th }}$ September 2009. This area is known to have frequent small scale earthquakes on-going as it is located in the tectonic slab between two major plates of Eurasian and Indo Australian plates. The research was conducted on the junior and senior high schools in Padang which are located in the earthquake-exposed area. These schools were reported having psychosocial problems among their pupils after earth quakes on $30^{\text {th }}$ September 2009 and $26^{\text {th }}$ October 2010 with 7.9 on the Richter scale and 6.8 on the Richter scale respectively [2]. The sample in the present study consisted of all students who were born in 19942000 and were exposed directly to the earthquake event stated. The population of the group aged 10 - 19 years old reported was 172, 175 adolescents [2].

\subsection{Sample Frame, Sampling Unit and Sample}

The sampling frame consists of a list of schools involved in the earthquake-exposed area (Figure 1). The data regarding the severity of destroyed school buildings were obtained from the educational department ministry in Padang to group into clusters of mild, moderate and severe clusters. From each cluster which was based on severity of damaged building, only one school was selected for each cluster. Therefore, there were 3 schools represented for junior and 3 schools represented for senior high schools. The junior schools represented for adolescent of age 12 - 15-year-old and the senior schools represented for 16 - 19 years old adolescents. From selected schools, one class was randomly selected by the school counsellor and all adolescents from the selected class were chosen as participants. The inclusion criteria were; the adolescent who was born in 19942000, exposed to the earthquake on $30^{\text {th }}$ September 2009 and stayed in Padang during data collection period. The minimal sample size was estimated using calculated PS2 Sample size with Fleiss JL (1981) method [10]. The calculated result was based on factors that determined PTSD among adolescents [11], with a confident interval of $95 \%$ and power of $80 \%$, the sample size required was 720 adolescents. The methodology flow chart was shown as in Figure 1.

\subsection{Study Instruments}

The instrument used was the self-administered questionnaire consisted of 3 


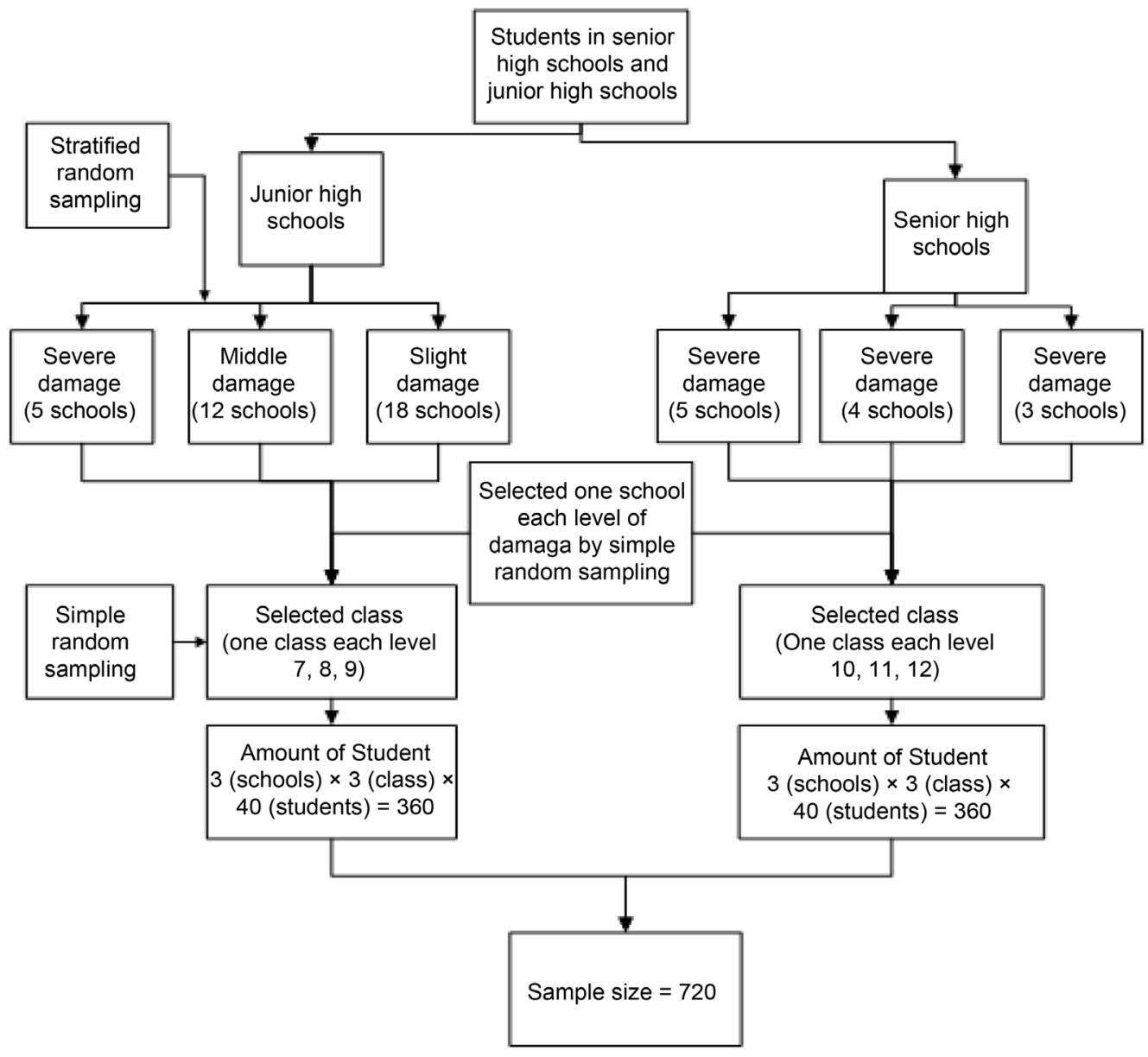

Figure 1. Methodological flow.

parts. Validated questionnaires used obtained with permission from several sources, including the local validated questionnaire [12]. The first and second part was focused on the information about adolescent characteristics, such as gender, age and family status. The second part consisted of measurements for PTSD in adolescents using 17 items for typical symptoms of PTSD according to the B, C and D criteria listed in DSM-IV using a revised University of California, Los Angeles Reaction Index (UCLA-RI) questionnaire [13]. The questionnaire was translated into Indonesian language. Validation done at pretest found that the internal consistency $(r)>0.195$, alpha Cronbach $>0.8$. The PTSD consists of three clusters symptom; re-experiencing, avoidance/ numbing and hyper-arousal symptoms. UCLA-Adolescent Version was used to measure symptoms of PTSD (17 items questionnaire with scale 0 - 4) with ranging from none problem, coded as 0 , to a lot of problems coded as 4 . The third part covered the psychosocial loss exposure to the earthquake assessed by a property destruction index with 6 items [11] and the coping strategy consisted of 5 items [14]. The validation for internal consistency on sub-variables of approach coping and also avoidance coping showed that both had $\mathrm{r}>0.195$ and the range of Alpha Cronbach of $0.7-0.8$. Questionnaire for self-efficacy was derived from Coppel's self-efficacy scale [13]. 
After validation, these items showed that the internally consistent with $\mathrm{r}>0.195$ and alpha cronbachs of 0.8 . The questionnaire for psychosocial loss was modified from Strand et al. [14] and Wickrama et al. [15] with only 9 items used. The validation for validated with Cronbach a coefficient ranged from 0.65 to 0.75 . To measure the trauma post-earthquake, the Earthquake Trauma Questionnaire of 14 items were used.

The conduct of the present study has been approved ethically by Universiti Kebangsaan Malaysia research ethic committee and permission to run this study has been obtained prior to data collection period.

\section{Results}

The characteristics of the respondents, family status and unhealthy lifestyles showed in Table 1 . The majority (60\%) of the respondents were from the middle

Table 1. Characteristic of respondents and family's status.

\begin{tabular}{|c|c|c|c|}
\hline \multicolumn{2}{|c|}{ Characteristic of adolescent } & \multirow{2}{*}{$\begin{array}{c}\mathbf{n} \\
212\end{array}$} & \multirow{2}{*}{$\begin{array}{c}\% \\
35.3\end{array}$} \\
\hline \multirow{3}{*}{ Age } & Early adolescent (12 - 14) & & \\
\hline & Middle adolescent (15 - 17) & 360 & 60 \\
\hline & Late adolescent $(>18)$ & 28 & 4.7 \\
\hline \multirow{2}{*}{ Gender } & Girl & 394 & 65.7 \\
\hline & Boy & 206 & 34.3 \\
\hline \multirow{3}{*}{ Parental status } & Married/have both of parent & 527 & 95.3 \\
\hline & Divorce/have only father/mother & 53 & 3.8 \\
\hline & No has both of parents (Orphan) & 5 & 0.8 \\
\hline \multirow{3}{*}{ Family income } & Low: <IDR*.353.838/person. & 171 & 29 \\
\hline & Middle: IDR 353.838 - 707.676/person. & 192 & 32 \\
\hline & High: >IDR 707.676/person. & 234 & 39 \\
\hline \multirow{8}{*}{$\begin{array}{l}\text { Paternal } \\
\text { education }\end{array}$} & Father & & \\
\hline & Low & 89 & 14.8 \\
\hline & Middle & 310 & 51.7 \\
\hline & High & 201 & 33.5 \\
\hline & Mother & & \\
\hline & Low & 87 & 14.5 \\
\hline & Middle & 317 & 52.8 \\
\hline & High & 196 & 32.7 \\
\hline \multirow{2}{*}{ Level of PTSD } & Non PTSD & 384 & 64.0 \\
\hline & PTSD & 216 & 36.0 \\
\hline \multirow{2}{*}{ Self-efficacy } & Normal self-efficacy & 262 & 43.7 \\
\hline & Low self-efficacy & 338 & 56.3 \\
\hline \multirow{2}{*}{ Earthquake Trauma } & Low & 362 & 60.3 \\
\hline & high & 238 & 39.7 \\
\hline \multirow{2}{*}{ Coping Strategy } & Positive & 280 & 46.7 \\
\hline & negative & 320 & 53.3 \\
\hline
\end{tabular}


adolescence age group (15 - 17 years old) and were studying in junior high and senior high schools in Padang City, West Sumatra. This is followed by the early adolescence (12 - 14 years old) and late adolescence age group ( $\geq 18$ years old). There were more girl respondents (65.7\%) than boys (34.3\%) participation. Most of the respondents (95\%) were adolescents who still had both parents (father and mother) and staying together with their families. Only a few of the respondents (4\%) had one parent. The largest group based on family income (39\%) were noted among those who have more than Rp. 707,676 per person, followed by $32 \%$ of middle class family income (Rp. 353,838 - 707,676 per person) and 29\% had low family income (income less than Rp. 353,838 per person). The highest parental education level was the middle education level (junior high and senior high school).

The distribution of the respondents' proportion in every variable was assessed and tabulated in Table 2. The prevalence of PTSD in the adolescents was 36.0\% $(n=216)$. There was $56.3 \%(n=338)$ of adolescents had low self-efficacy and the majority suffered from low earthquake trauma $(60 \%)$. The proportion of adolescents with negative coping was found in $53.3 \%(\mathrm{n}=320)$ of them.

Table 2 showed the relationship between adolescents' characteristics, family status and cognitive factors (coping strategy and self-efficacy) with PTSD. The factors that had a significant relationship with the occurrence of PTSD were the adolescent's age $(\mathrm{P}<0.01)$, gender $(\mathrm{P}<0.01)$, coping strategy ( $\mathrm{P}$-value $<0.01)$ and self-efficacy $(P=0.02)$. However, other factor shown no significant relationship (P-value $\geq 0.05$ ) with the occurrence of PTSD such as parental status, family income, parent's educational status. It was found weak correlation $(\mathrm{r}=$ 0.16 ) between the age of the respondents and the PTSD. Figure 2 showed that the older the age of the adolescent had higher risk of PTSD. A weak $(r=-0.18)$ relationship found between the coping strategy and the PTSD. The number of adolescents with negative coping (320 respondents) was more than those with positive coping (280 respondents). The proportion of adolescents who experienced PTSD were higher in the adolescents with negative coping (41.2\%) compared to those with positive coping (30.0\%) (Table 2). Figure 3 also shows the effect of coping strategies on PTSD among adolescents. The figure shows that there is a relationship between the coping strategy and the occurrence of PTSD. The bivariate test showed that there is a significant relationship between self-efficacy and the occurrence of PTSD with P-value of 0.022 (Table 2) and weakly correlated $(r=0.13)$ as showed in Figure 4 . The proportion of respondents who experienced PTSD was higher for the respondents with lower self-efficacy (39.9\%).

\section{Discussion}

The characteristic findings found in this study were in accordance with the population data of Padang city [1]. Being an older aged adolescent will have more responsibility to their family, while the younger adolescents still have sense 
Table 2. Relationship between independent variables with PTSD.

\begin{tabular}{|c|c|c|c|c|c|c|}
\hline & Characteristic & Sum & $\begin{array}{c}\text { Non } \\
\text { PTSD (\%) }\end{array}$ & PTSD (\%) & $\mathrm{X} 2$ & $\mathbf{P}$ \\
\hline \multicolumn{7}{|c|}{ Characteristic of adolescent } \\
\hline \multirow[t]{3}{*}{ Age } & Early adolescent & 212 & $160(75.5)$ & $52(24.5)$ & \multirow[t]{2}{*}{18.95} & \multirow[t]{2}{*}{$<0.01$} \\
\hline & Middle adolescent & 360 & $209(58.1)$ & $151(41.9)$ & & \\
\hline & Late adolescent & 28 & $15(53.6)$ & $13(46.4)$ & \multirow{3}{*}{13.04} & \multirow{3}{*}{$<0.01$} \\
\hline \multirow[t]{2}{*}{ Gender } & Boy & 206 & $152(73.8)$ & $54(26.2)$ & & \\
\hline & \multirow[t]{2}{*}{ Girl } & 394 & $232(58.9)$ & $162(41.1)$ & & \\
\hline \multicolumn{6}{|c|}{ Family status } & \\
\hline \multirow[b]{2}{*}{$\begin{array}{l}\text { Parental } \\
\text { status }\end{array}$} & $\begin{array}{l}\text { Married/both } \\
\text { parent present }\end{array}$ & 572 & $368(64.3)$ & $204(35.7)$ & \multirow[t]{2}{*}{1.37} & \multirow[t]{2}{*}{0.50} \\
\hline & $\begin{array}{c}\text { Divorce/either one } \\
\text { parent present }\end{array}$ & 23 & $14(60.9)$ & $9(39.1)$ & & \\
\hline \multirow{4}{*}{$\begin{array}{l}\text { Family } \\
\text { income }\end{array}$} & Orphan & 5 & $2(40)$ & $3(60)$ & \multirow{4}{*}{0.49} & \multirow{4}{*}{0.78} \\
\hline & Low & 176 & $109(61.9)$ & $67(38.1)$ & & \\
\hline & Middle & 193 & $126(65.3)$ & $67(34.7)$ & & \\
\hline & High & 231 & $149(64.5)$ & $82(38.5)$ & & \\
\hline \multicolumn{7}{|c|}{ Paternal education } \\
\hline \multirow{3}{*}{ Father } & High & 89 & $58(65.2)$ & $31(34.8)$ & \multirow{2}{*}{0.12} & \multirow[t]{2}{*}{0.94} \\
\hline & Middle & 310 & $199(64.2)$ & $111(35.8)$ & & \\
\hline & Low & 201 & $127(63.2)$ & $74(36.0)$ & \multirow{4}{*}{0.91} & \multirow[b]{2}{*}{0.63} \\
\hline \multirow{3}{*}{ Mother } & High & 87 & $52(59.8)$ & $35(40.2)$ & & \\
\hline & Middle & 317 & $207(65.3)$ & $110(34.7)$ & & \\
\hline & Low & 196 & $125(63.8)$ & $71(36.2)$ & & \\
\hline Earthquake & Low & 362 & $241(66.6)$ & $121(33.4)$ & \multirow{2}{*}{2.62} & \multirow{2}{*}{0.11} \\
\hline Trauma & High & 237 & $142(60.1)$ & $95(39.9)$ & & \\
\hline \multirow{2}{*}{$\begin{array}{l}\text { Coping } \\
\text { Strategy }\end{array}$} & Positive & 280 & $196(70.0)$ & $84(30.0)$ & \multirow[t]{2}{*}{8.10} & \multirow[t]{2}{*}{$<0.01$} \\
\hline & Negative & 320 & $188(58.8)$ & $132(41.2)$ & & \\
\hline \multirow{2}{*}{ Self-efficacy } & High & 262 & $181(69.1)$ & $81(30.9)$ & \multirow[t]{2}{*}{5.21} & \multirow[t]{2}{*}{0.02} \\
\hline & Low & 338 & $203(60.1)$ & 135 (39.9) & & \\
\hline
\end{tabular}

of dependence to older adults. The adolescence is at the age of transitional period between being children and being an adult human. At this time, the change occurs both physically and mentally may expose the adolescents to susceptibility to stress of hormonal change. The results of the present study are consistent with the results of a study conducted by Hizli, et al. [15] in Ankara Turkey, Wei Y et al. [16] in China and Prashantham et al. [17] in India. Hizli et al. [15] reported that adolescents in older age group (14 - 18 years old) had higher percentages of PTSD (23.9\%) than adolescents in younger age group ( 8 - 13 years old) who had percentages of PTSD of 19.5\%. A study [17] conducted 2 - 6 months 


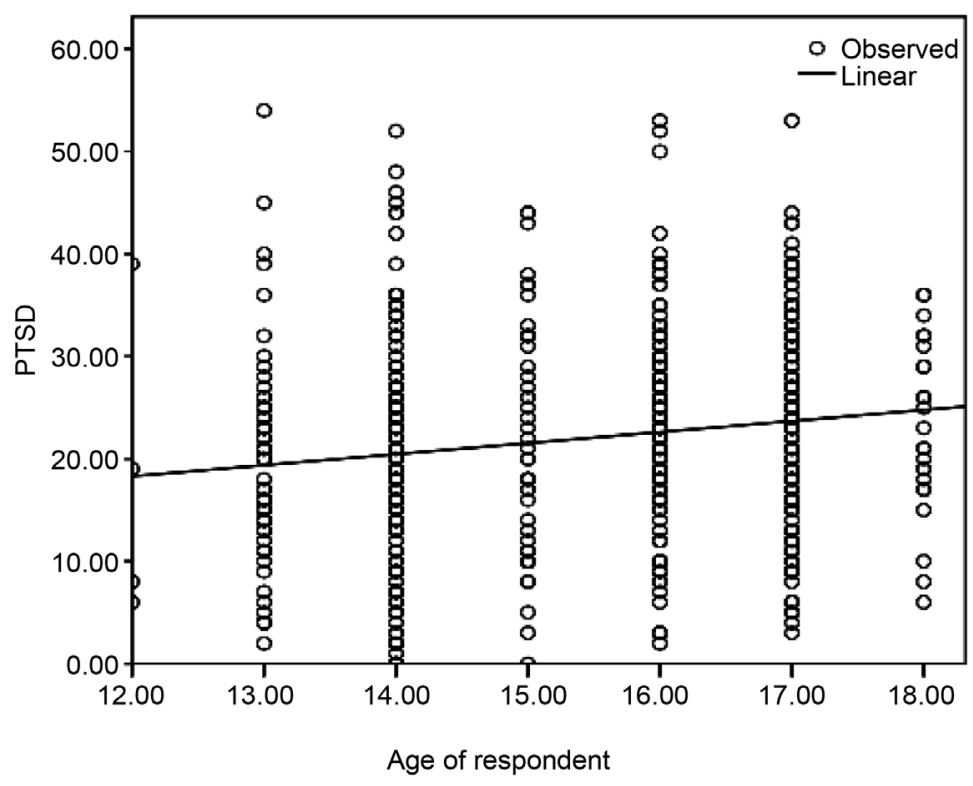

Figure 2. Effect of age on PTSD among adolescent.

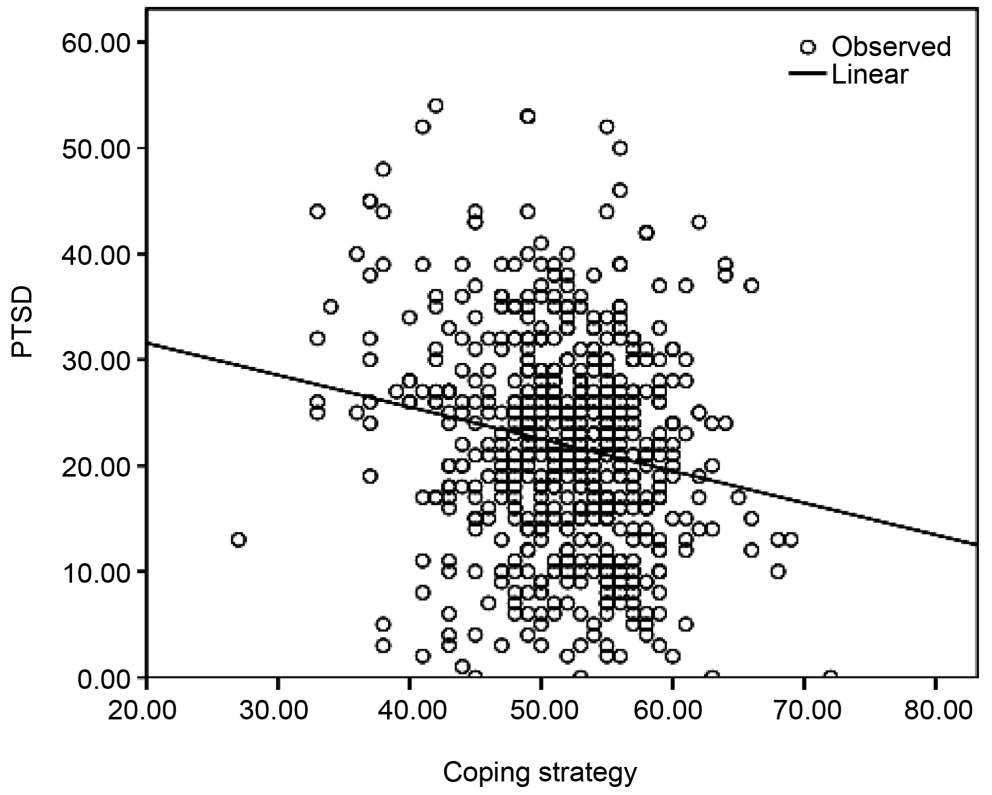

Figure 3. Effect coping strategy on PTSD among adolescents.

after the tsunami in Tamil Nandu for children and adolescents in an age group of 6 - 18 years old; found that PTSD was highest in children of ages $12-18$ years old.

There is a significant relationship between the gender of the adolescent and PTSD. Girls were more predominantly affected than boys. Girls tend to be more stressful when facing problems and are more vulnerable to fall into an emotional life, while the boys tend to be more resistant to the stress. The finding is consistent with earlier study by Mule CM [18]. That paper has revealed that girls appear to have higher rates of depression than boys which caused by environmental 


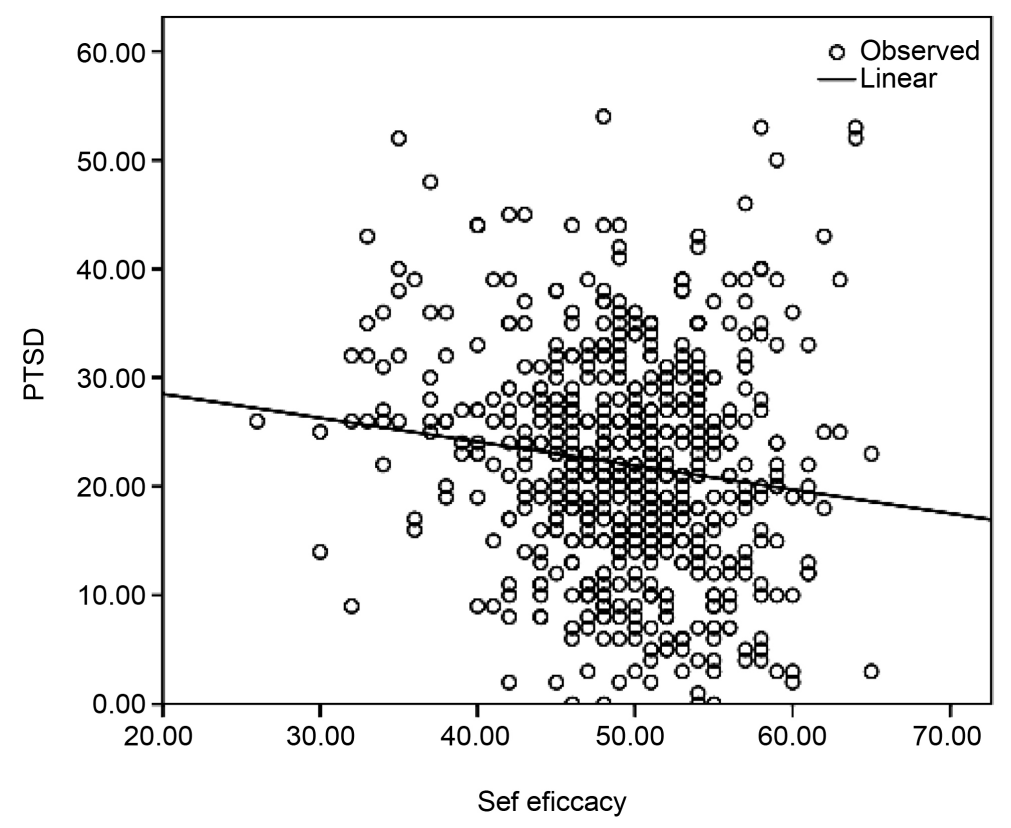

Figure 4. Effect self-efficacy on PTSD among adolescents.

factors that were included in the gender stereotypes and identity roles. The susceptibility of depression in girls were related to biological determinant, environmental factors and role in facing life events have been documented but no clear linked of evidence seen in human study.

The coping strategy is a very useful thing to use as a buffer for a person in order to reduce the occurrence of PTSD. Coping strategies are very important for the use of every individual to face problems in their lives, especially regarding mental health problems such as traumatic experiences in life. Coping can be described as a strategy, cognition tactics or behavior. Coping is a phenomenon that can be identified through introspection or observation and it can be related to internal events as well as the external environment. Good coping ability is required for adolescents to be able to solve their problems well [7] [19].

Higher self-efficacy in the respondent causing reduced occurrences of PTSD. This is understandable because self-efficacy can play a major role in reducing the negative impact of stress on health [20] [21]. The adolescents with high self-efficacy were commonly seen in a more mature age [20]. There was a relationship between self-efficacy and better emotional health among adolescents [21].

If this study was continued, they would probably have a weak relation with PTSD, as other researchers have shown that parental status has an impact on the lives of family members, especially their adolescents. A trend is seen based on earlier studies [22]-[27] that various problems arise among families whose parents have divorced and this will influence the adolescents to risky social problem habit like promiscuity, brawling, gambling, smoking, drinking, speeding on the streets and have a lack of courtesy towards older people. However, the present study did not find significant association between parental status and PTSD. Some of the adolescents use negative behavior to cope when faced with a prob- 
lem. The absence of one of their parents can be symbolically interpreted by the adolescents as a form of rejection. These things can affect the emotions and cognitions of the adolescents, including their coping skills [28].

\section{Conclusion}

The present study results showed that there was a significant relationship between the occurrence of PTSD and the studied factors such as adolescent's age, gender, coping strategies and self-efficacy. However, other factors had no significant relationship with the occurrence of PTSD such as parental status, family income and parents' educational status. There was a higher proportion of PTSD among the older age adolescents rather than the younger age adolescents. The girls were more likely to get PTSD than the boys. Coping strategies were very useful to use as a buffer for a person to prevent PTSD. Higher self-efficacy was a factor found reducing the occurrence of PTSD in the adolescents. Therefore, active screening on mental and sexual reproductive health among the adolescents is important in the vulnerable area like earthquake prone area in Padang. Traumatic event can anticipated more mental health problems likes PTSD as shown higher percentages affected. School teachers, parents and the non-governmental volunteer support groups should continue to give emotional and motivational supports to the affected adolescents in order to boost up their self-efficacy and coping skills.

\section{Acknowledgements}

The authors would like to thank the Universiti Kebangsaan Malaysia for their financial support under FF-095-2012 grants.

\section{References}

[1] Statistics Indonesia (BadanPusatStatistik-BPS) and Macro International (2008) Indonesia Demographic and Health Survey 2007. BPS and Macro International, Calverton. https://dhsprogram.com/pubs/pdf/FR218/FR218[27August2010].pdf

[2] Bijak blog (2016) Korban Tewas Gempa Sumbar Menjadi 809 Orang. http://xx-gempa.blogspot.co.id/2009/10/korban-tewas-gempa-sumbar-menjadi-809. $\underline{\mathrm{html}}$

[3] Adesla, V. (2009) Post-Traumatic Stress Disorder (PTSD). https://cpl.psy.msu.edu/wp-content/uploads/2010/05/Moser-et-al.-2007.pdf

[4] NIMH (2008) Post-Traumatic Stress Disorder. https://www.nimh.nih.gov/health/topics/post-traumatic-stress-disorder-ptsd/index. $\underline{\text { shtml }}$

[5] Gosselin, J.T. and Maddux, J.E. (2003) Self-Efficacy. Psychology Faculty Publications. Paper 17. http://digitalcommons.sacredheart.edu/psych fac/17

[6] Allen, A.B. and Leary, M.R. (2010). Self-Compassion, Stress, and Coping. Social and Personality Psychology Compass, 4, 107-118. https://doi.org/10.1111/j.1751-9004.2009.00246.x

[7] Johnson, D.W. and Johnson, R.T. (1995) Cooperative versus Competitive Efforts and Problem Solving. Review of Educational Research, 65, 129-143. 
https://doi.org/10.3102/00346543065002129

[8] World Health Organization (2014) Health for the World's Adolescents: A Second Chance in the Second Decade.

http://www.who.int/maternal child adolescent/documents/second-decade/en/

[9] President of Republic Indonesia (2002) Laws of Republic of Indonesia No.23, 2002 on Child Protection.

http://www.arnec.net/wp-content/uploads/2015/03/ANNEX-3-Laws-of-child prote ction.pdf

[10] Fleiss, J.L., Levin, B. and Paik, M.C. (2004) Statistical Methods for Rates and Proportions. Third Edition, Wiley Series in Probability and Statistics, Hoboken.

[11] Giannopoulou, I., Strouthos, M., Smith, P., Dikaiakou, A., Galanopoulou, V. and Yule, W. (2006) Post-Traumatic Stress Reactions of Children and Adolescents Exposed to the Athens 1999 Earthquake. European Psychiatry, 21, 160-166.

[12] Hatake, K. (2013) Pelayanan Kesehatan Peduli Remaja (PKPR). http://macrofag.blogspot.com/2013/03/makalah-pkpr-pelayanan-kesehatan-peduli. $\underline{\mathrm{html}}$

[13] Coppel, D.B. (1980) The Relationship of Perceived Social Support and Self-Efficacy to Major and Minor Stressors. Unpublished Doctoral Dissertation, University of Washington.

[14] Strand, V.C., Pasquale, L.E. and Sarmiento, T.L. (2011) Child and Adolescent Trauma Measures: A Review.

http://www.ncswtraumaed.org/wp-content/uploads/2011/07/Child-and-Adolescent -Trauma-Measures A-Review-with-Measures.pdf

[15] Wickrama, K.A.S. and Kaspar, V. (2006) Family Context of Mental Health Risk in Tsunami-Exposed Adolescent: Findings from Pilot Study in Sri Lanka. Social Science \& Medicine, 64, 713-723.

[16] Hizli, F.G., Taskin Tuna, N., Isikli, S., Kilic, C. and Zileli, L. (2008) Predictors of Posttraumatic Stress in Children and Adolescents. Children and Youth Services Review, 31, 349-354.

[17] Wei, Y., Wang, L., Wang, R., Cao, C., Shi, Z. and Zhang, J. (2013) Prevalence and Predictors of Posttraumatic Stress Disorder among Chinese Youths after an Earth quake. Social Behavior and Personality, 41, 1613-1624. https://doi.org/10.2224/sbp.2013.41.10.1613

[18] Prashantham, B., Russell, S. and Russell, P.S.S. (2007) The Prevalence of Posttraumatic Stress Disorder among Children and Adolescents Affected by Tsunami Disaster in Tamil Nadu. Journal of Emergency Nursing, 5, 3-7.

[19] Mule, C.M. (2004) Why Women Are More Susceptible to Depression: An Explanation for Gender Differences. Rochester Institute of Technology. http://www.personalityresearch.org/papers/mule.html

[20] Lever, J.P. (2008) Poverty, Stressful Life Events, and Coping Strategies. The Spanish Journal of Psychology, 11, 228-249. https://doi.org/10.1017/S1138741600004273

[21] Peterson, A.C. (1998) Adolescent: A Developmental Approach to Problems and Psychopathology. Behavior Therapy, 17, 480-499.

[22] Weeks, D. and Savedra, M. (1988) Adolescent Cancer: Coping with Treatment-Related Pain. Journal of Pediatric Nursing, 3, 318-328.

[23] Hoffman, C.D. and Ledford, D.K. (1995) Adult Children of Divorce: Relationships with Their Mothers and Fathers Prior to, Following Parental Separation, and Currently. Journal of Divorce \& Remarriage, 24, 41-57. 
https://doi.org/10.1300/J087v24n03 03

[24] Westervelt, K. and Vandenberg, B. (1997) Parental Divorce and Intimate Relationships of Young Adults. Psychological Reports, 80, 923-926.

https://doi.org/10.2466/pr0.1997.80.3.923

[25] Nielsen, L. (1999) College Aged Students with Divorced Parents: Facts and Fiction. College Student Journal, 33, 543.

[26] Van Shaick, K. and Stolberg, A.L. (2001) The Impact of Parental Involvement on Young Adults' Intimate Relationships. Journal of Divorce \& Remarriage, 36, 99. https://doi.org/10.1300/J087v36n01 06

[27] Kirk, A. (2002) The Effects of Divorce on Young Adults' Relationship Competence: The Influence of Intimate Friendships. Journal of Divorce \& Remarriage, 38, 61. https://doi.org/10.1300/J087v38n01 04

[28] Hopf, S.M. (2010) Risk and Resilience in Children Coping with Parental Divorce. Dartmouth Undergraduate Journal of Science.

http://dujs.dartmouth.edu/2010/05/risk-and-resilience-in-children-coping-with-par ental-divorce/\#.WWZSB4SGPcS

\section{Scientific Research Publishing}

Submit or recommend next manuscript to SCIRP and we will provide best service for you:

Accepting pre-submission inquiries through Email, Facebook, LinkedIn, Twitter, etc. A wide selection of journals (inclusive of 9 subjects, more than 200 journals) Providing 24-hour high-quality service User-friendly online submission system Fair and swift peer-review system Efficient typesetting and proofreading procedure Display of the result of downloads and visits, as well as the number of cited articles Maximum dissemination of your research work

Submit your manuscript at: http://papersubmission.scirp.org/ Or contact health@scirp.org 